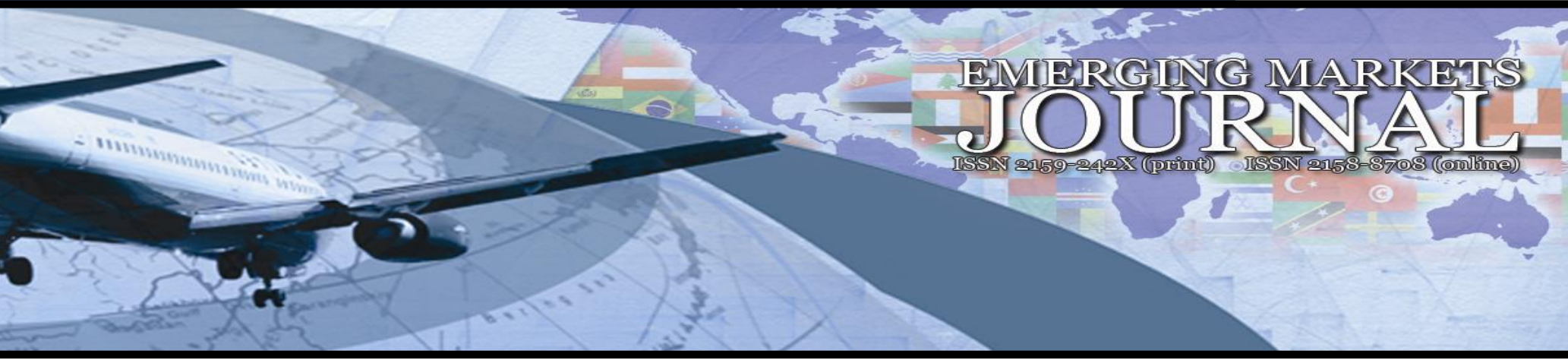

\title{
Sustainability in Career Development: The Impact of Career Development Culture and Career Support of Senior Management on Career Satisfaction
}

\author{
Widana Pathiranage Richard Wickramaratne \\ University of Peradeniya - Sri Lanka I wp_richard@yahoo.com
}

Volume 10 No 2 (2020) ｜ＩSSN 2158-8708 (online) ｜ＤOI 10.5195/emaj.2020.194｜ http://emaj.pitt.edu

\begin{abstract}
The study examined whether career development culture and career support of senior management impact employee career satisfaction. This study validated two new questionnaires: career development culture and career support of senior management. Based on the extended model of social cognitive career theory, the study proposed that these two variables positively impact on employee career satisfaction. Private sector employees $(\mathrm{N}=196)$ representing a range of manufacturing and service sector firms from the private sector in Sri Lanka participated in a survey. It is found that, career development culture and the career support of senior management positively impact on career satisfaction. The current findings provide implications to the extended model of social cognitive career theory by testing the hypothesized relationships with a cross sectional study. The current findings propose that an organization should develop a career development culture and the senior management should support employees' career development in such a way that increases their career satisfaction. The study is subject to common method and common source bias, since this is a cross sectional study with a survey. Future research could be conducted with the representation of broader category of employees and industries, which promotes the generalizability of findings.
\end{abstract}

Keywords: Business, management and organization, career development culture, career support of senior management, career satisfaction

\section{$(\mathrm{cc}) \mathrm{EY}$}

New articles in this journal are licensed under a Creative Commons Attribution 3.0 United States License.

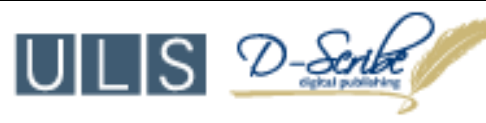

This journal is published by the University Library System of the University of Pittsburgh as part of its D-Scribe Digital Publishing Program, and is cosponsored by the University of Pittsburgh Press. 


\section{Sustainability in Career Development: The Impact of Career Development Culture and Career Support of Senior Management on Career Satisfaction}

\section{Widana Pathiranage Richard Wickramaratne}

\section{Introduction}

Scholars who are in the areas of management and vocational/organizational psychology have a strong interest on the notion of a protean career orientation (PCO), which describes individuals who are responsible for their own career development instead of the organizations' career development responsibility (Hirschi, Jaensch, and Herrmann, 2016). However, individuals do not develop or define themselves in a contextual vacuum, and alongside this focus on identity, many authors highlight the pivotal role that environment plays in identity formation and career development. Thus, other people play a significant part in an individual's career development and many theories acknowledge the inevitable and often valuable role that other people play in career decisions (Yates, 2020).

Therefore, despite the growing emphasis of career self-management, contemporary organizations play an integral role in developing the careers of their employees. This dual responsibility of career development is partly linked to the notion of sustainable careers. Sustainable careers consist of work experiences across one's lifespan that also intersect multiple life domains such as work, social, and family (Van der Heijden \& De Vos, 2015). Accordingly, fundamental to the sustainable career concept, there is a shared responsibility between employers and employees for developing employee careers (Van der Heijden, 2005; Veld, Semeijn, \& Van Vuuren, 2015).

In terms of sustainability concept, organizations make use of their career development programs as a creative way of meeting the challenges of attraction, retention and motivation of their employees (Erdogan et al., 2004; Heslin, 2005). One way that organizations may meet this challenge is to support employees to develop their own careers and increase their career satisfaction (Barnett and Bradley, 2007; Baruch, 2006). Organizational support for career development (OSCD) is also called "organizational career management" or "organizational sponsorship" and refers to the programs, processes and assistance provided by organizations to support and enhance their employees' career success ( $\mathrm{Ng}$ et al., 2005; Orpen, 1994). OSCD comprises formal strategies (including career planning, training and assessment centres) and informal support such as providing mentoring, coaching and networking opportunities (Hall, 2002; London, 1988; Sturges, Guest, Conway, and Davey, 2002).

The extended model of social cognitive career theory (Lent \& Brown, 2006), suggests that the organizational support for career development such as organizational career development opportunities and career oriented perceived organizational support belong to a class of environmental support and resource variables that are specifically relevant to the pursuit of an individual's career goals. Therefore, the organizational support for career development provide social and material support for one's personal goals and so are likely to be significant predictors of employee outcomes such as, career satisfaction (Barnett \& Bradley, 2007; Lent \& Brown, 2006, Ng et al; 2005).

In sum, the extant literature support the fact that organizational career development support factors such as career planning, training $\&$ assessment centres, mentoring, coaching, networking opportunities as well as employee perceptions of organizational career support, have a positive impact on career satisfaction. However, no prior empirical studies are found, which have tapped career development culture and senior management career support as organizational support factors in this relationship. Therefore, the overarching research problem of this study is to investigate whether career development culture and senior management career support positively impact employee career satisfaction. The findings of this research are expected to provide implications to the extended model of social cognitive career theory (Lent and Brown, 2006) and to provide policy implications to have sustainable careers at work place, which benefit both employers and employees. The conceptual framework that guide this study is provided in figure 1 .

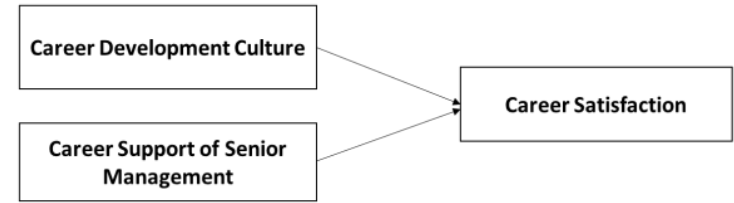

Figure 1. Conceptual Framework

Source: Developed by the Author

\section{Key Model Elements and Hypotheses}

\section{Career satisfaction}

Traditional career studies focused mainly on objective measures of career satisfaction (Gattiker and Larwood, 1988) such as status, promotions and salary (Seibert and Kraimer, 2001). However, having achieved objective career satisfaction does not necessarily mean that people are satisfied with their career (Hall, 2002) and some objective career satisfaction measures are likely to be less relevant today, since organizations are more controlled in providing these opportunities (Heslin, 2005). Therefore, this study relies on subjective career satisfaction which measures in terms of the extent to which individuals believe their career progress is consistent with their own goals, values and preferences (Erdoganet al., 2004; Heslin, 2003; Seibert and Kraimer, 2001). 


\section{Career development culture}

To explain the role of culture in HRM, 'the model of culture fit' was proposed by Kanungo and his associates (Aycan et al., 1999; Mendonca \& Kanungo, 1994). This model assessed culture at two levels: societal and organizational. Organisational culture consists of beliefs, values, and assumptions that are commonly shared by members of an organization, and these values influence the behavior of organizational members since people rely on these values to guide their decisions and behaviors (Schein, 1985). In other words, the organizational culture consists of managerial beliefs and assumptions about tasks and employees. Managerial assumptions relating to tasks deal with the nature of the task and how it must be best achieved, while managerial assumptions relating to employees deal with the nature and behaviorr of employees (Aycan, 2005). Employee related assumptions are also influenced by the characteristics of the socio-cultural context via the mediation of internal work culture (Aycan, 2005). For example, in career management, career behaviorr such as initiatives and interventions to shape future careers is less common in high power distance cultures (Claes \& RuizQuintanilla, 1998). Similarly, in paternalistic cultures career decisions are influenced significantly by others such as family, friends and superiors (Aycan \& FikretPasa, 2003). Consequently, in high power distance and paternalistic cultures, employees seek and accept guidance of their superiors, who are perceived to be aware of what is good for employees' professional development (Aycan, 2005).

In relation to career development, Kotter and Heskett (1992) propose that the organizational culture has two levels namely, deeper and less visible level and the more visible level. According to them, at the deeper and less visible level, culture refers to values shared by the organizational members which constitute the driving force for a development culture. At the more visible level, culture represents behavior patterns or style of an organization and these behaviors may need to be changed in building a development culture. Development culture is one in which individuals grow in ways needed by the organization. In a development culture, employees are expected to grow, supported in their efforts to do so, and are rewarded for success as measured by their contributions (Simonsen, 1997, p. 4).

There are some main characteristics of a development culture. They are; trust, openness, collaboration, managed conflict, risk taking, systems aligned with messages, and learning organization (Simonsen, 1997). Trust is the most important ingredient in any corporate change process (Laabs, 1996). Openness can be achieved by keeping the organizational structures as open as possible, encouraging participation and role exchange among employees (Gottlieb \& Conkling, 1995). Similarly, both formal and informal communication systems must be open in order for employees to develop. Consequently, organizational leaders must define strategic direction of the firm and both suggestions and complaints must be encouraged (Simonsen, 1997). Career development is not about beating out the competition for a promotion, but about successful collaboration/teamwork so that everyone is adding value through the achievement of team goals and organizational success (Simonsen, 1997). In a development culture, conflict is managed rather than avoided and everyone has and uses skills to move from argument to planning for solutions.

Consequently, the outcome of conflict situations becomes problem solving rather than ongoing disagreement (Simonsen, 1997). A development culture encourages risk taking. Risk taking is rewarded, not punished and innovation as a result of risk taking is celebrated (Simonsen, 1997). Compensation systems reward employees based on the actual contribution rather than tenure or position; intrinsic rewards such as respect and acknowledgement, and showing employees that their work are valued. If employees are expected to be selfdirected, then decision making systems allow and support that behaviour (Simonsen, 1997).

Prior studies provide some clues about the impact of development (learning) culture on some career related outcomes such as career satisfaction and organizational commitment (Joo \& Park, 2010). Similarly, Japanese overseas subsidiaries reflected greater influences of parent company culture on their career counselling and planning activities (Yuen \& Kee, 1993). Conversely, when employees don't feel that they fit with the culture of their organization, it may also be perceived as a barrier to their career advancement (Briggs, Jaramillo, \& Weeks, 2011).

\section{Career support of senior management}

Generally, it is well accepted that there is an involvement of HR at corporate level (Huselid., 1995; Schuler \& Jackson, 1987). Particularly, senior management support is an essential element of every comprehensive and integrated career development systems. In relation to career, it's well recognized that, career development is a tool for strategic control and development (Evans, 1987). Consequently, career planning and management have a huge impact on whether organizations can attain corporate goals and individuals can meet their personal aspirations. Therefore, to successfully manage careers, a strategy is required aimed at having a comprehensive framework for attracting, developing, and retaining employees in accordance with business objectives (Mayo, 1991; Walters, 1992). Therefore, active support from senior management is vital to a comprehensive and sustainable career development process (Simonsen, 1997).

In support of this argument, a survey conducted in Canadian context revealed that career development programs need considerable co-ordination within a company, particularly from the support and direction of senior management (Portis, 1978). For example, senior management can pilot the career development process, participate in career discussions, and set their own development goals (Simonsen, 1997). Furthermore, senior management needs to pay greatest attention to career planning activities such as periodic progress reviews of managers and identification of strengths, weaknesses and training needs (Portis, 1978). Prior literature provide evidence that the senior management support for career development is related to some career variables such as career development and employee career opportunities (Kraimer, Seibert, et al., 2011).

Prior research outcomes of the positive relationship between organizational support for career development and career satisfaction (Allen, Eby, Poteet, Lentz, \& Lima, 2004; Barnett \& Bradley, 2007; Guan et al., 2015; Guan et al., 2014; Lent \& Brown, 2006; Ng et 
al., 2005; Orpen, 1994; Pazy, 1988; Price \& Reichert, 2017) and the prediction of the extended model of social cognitive career theory (Lent, 2004, 2005; Lent and Brown, 2006) led to the study's two hypotheses:

Hypothesis 1- Career development culture has a positive impact on career satisfaction of employees

Hypothesis 2- Senior management support has a positive impact on career satisfaction of employees

\section{Method}

Sample

This research is an explanatory study with a quantitative data collection approach. An online survey was distributedto 400 employees representing a range of manufacturing and service sector firms from the private sector in Sri Lanka. Out of total responses of 196, 60\% of respondents were managerial employees whereas 40 of employees were in the administrative and technical capacities. Of the total responses received, $62 \%$ were female. The majority of respondents were aged between 36 and 45 years (69 per cent), with 20 percent under 36 years and 11 percent aged over 45 years. Most of the respondents (47 percent) were employed with their current organization between 5-10 years, with 10 percent having organizational tenure of less than 5 years and 43 percent over 11 years. Educational level was at a high level with 72 percent of respondents having completed either undergraduate or postgraduate qualification.

\section{Measures}

All the study variables were measured on a five-point scale, which ranged from strongly agree (5) to strongly disagree (1). All the scale items were averaged to obtain an overall measure for each of the variables. Career development culture- The career development culture is defined merely for the purpose of this current study as "career development culture is one in which individuals progress in their careers in ways needed by the organization and the individuals, with the organization's support in terms of systems, management support as well as rewards in their efforts to do so'. The measures and scales for the career development culture is based on measures and scales developed by Simonsen (1997) for development culture. However, as shown in Table 1 , these measures and scales were modified to make them more appropriate for a career development culture.

Table 1: Scale of Career Development Culture

\begin{tabular}{|c|c|}
\hline Measures & Questionnaire items \\
\hline $\begin{array}{l}\text { Extent of use of } \\
\text { organizational } \\
\text { systems that } \\
\text { support career } \\
\text { development }\end{array}$ & $\begin{array}{l}\text { 1. Our organization values } \\
\text { managers those who support } \\
\text { to develop careers of their } \\
\text { employees. } \\
\text { 2. We have systems such as job } \\
\text { posting and position } \\
\text { descriptions that provide } \\
\text { information about career } \\
\text { opportunities in the } \\
\text { organization. } \\
\text { 3e have } \\
\text { communications so employees } \\
\text { can gain information about }\end{array}$ \\
\hline
\end{tabular}

\begin{tabular}{|c|c|}
\hline & $\begin{array}{l}\text { career opportunities in the } \\
\text { organization } \\
\text { 4. Managers and employees' } \\
\text { responsibilities for career } \\
\text { development are clearly } \\
\text { identified and stated. } \\
\text { 5. Our organization does not } \\
\text { provide access to career } \\
\text { assessment and planning } \\
\text { tools/materials for employees } \\
\text { (R). } \\
\text { 6. Our organization provides } \\
\text { career development for } \\
\text { managers and employees. }\end{array}$ \\
\hline $\begin{array}{l}\text { Extent of } \\
\text { managers, } \\
\text { contributions to } \\
\text { the career } \\
\text { development of } \\
\text { employees }\end{array}$ & 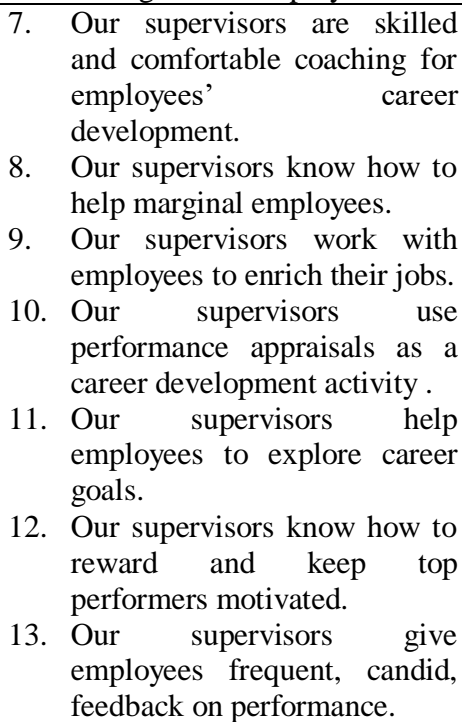 \\
\hline $\begin{array}{l}\text { Extent of } \\
\text { employees needs } \\
\text { and awareness of } \\
\text { responsibility for } \\
\text { their own career } \\
\text { development }\end{array}$ & $\begin{array}{l}\text { 14. } \begin{array}{l}\text { Our employees do not seek } \\
\text { feedback about their } \\
\text { performance from their } \\
\text { supervisors (R). }\end{array} \\
\text { 15. Employees here initiate new } \\
\text { work procedures, activities } \\
\text { and responsibilities that helps } \\
\text { their careers. } \\
\text { 16. Employees have written career } \\
\text { development plans. } \\
\text { 17. Our new supervisors are } \\
\text { trained in supporting the } \\
\text { career development of } \\
\text { subordinates. } \\
\text { 18. Employees like to work, and } \\
\text { develop their careers as } \\
\text { demonstrated by high morale. } \\
\text { 19. Our professional/technical } \\
\text { employees can develop their } \\
\text { own careers without moving } \\
\text { to managerial positions. }\end{array}$ \\
\hline
\end{tabular}

Career support of senior management- Career support of senior management is defined solely for this study as 'senior managers' contribution to the career development of employees in terms of leadership, encouragements, active participation, and effective communication'. Simonsen's (1997) measures and scales for the senior management's support for development were modified to identify the measures and scale items of career support of senior management which are given in Table 2. 
Table 2: Scale of Career Support of Senior Management

\begin{tabular}{|c|c|}
\hline Measures & Questionnaire items \\
\hline Career leadership & $\begin{array}{l}\text { Senior managers provide } \\
\text { leadership for career } \\
\text { development culture change. }\end{array}$ \\
\hline $\begin{array}{l}\text { Encouragement and } \\
\text { participation }\end{array}$ & $\begin{array}{l}\text { 2. Senior managers do not } \\
\text { provide role models to get } \\
\text { their people to change in } \\
\text { terms of career development } \\
\text { (R). } \\
\text { 3. Senior managers provide } \\
\text { continued encouragement } \\
\text { for participation in career } \\
\text { development. } \\
\text { 4. Senior managers participate } \\
\text { in training to discuss } \\
\text { differences on the } \\
\text { assessment as part of career } \\
\text { discussion. }\end{array}$ \\
\hline $\begin{array}{l}\text { Top management } \\
\text { communication }\end{array}$ & $\begin{array}{l}\text { 5. Senior managers } \\
\text { communicate the importance } \\
\text { for everyone to be involved } \\
\text { in the career development } \\
\text { process. } \\
\text { 6. We receive communications } \\
\text { from top management } \\
\text { promoting the career } \\
\text { development program } \\
\text { purposes, need for changes, } \\
\text { and expressing high level } \\
\text { expectations. }\end{array}$ \\
\hline
\end{tabular}

Career Satisfaction- Career satisfaction was measured using the five-item career satisfaction scale developed by Greenhaus et al. (1990), which has demonstrated an internal consistency correlation of 0.86. A sample questionnaire item is "I am satisfied with the progress I have made toward meeting my overall career goals".

Control variables- Respondents' demographic information was collected with single item questions for gender, age, highest level of education completed, organizational tenure and work type (technical, professional, managerial).

Procedure

This study is conducted based on five best work places in Sri Lanka identified by the LMD business magazine (2019). These firms were identified randomly, which covers industries such as insurance, fast food, textile, consumer durables and telecommunication. Thirty online surveys were distributed to each firm with the assistance of the HR department. Each of the HR department was advised to distribute the online survey links among a randomly selected sample of managerial, administrative and technical level employees.

\section{Results}

The data analysis was conducted in two stages using the version 24 of the SPSS software: Validating the career development culture and senior management's career support questionnaires and testing the hypotheses. The questionnaire validation was done with three stages. First, the face validity of questionnaires were tested with five senior HR executives, who are from the sample organizations and did some modifications to the questionnaires based on their responses. Second, a pilot test was conducted with a total number of 15 respondents by selecting 3 managerial, technical and administrative level employees from each of the sample organizations. The purpose of the pilot test is to refine the questionnaires to assure that the respondents do not have any problems in responding to the survey as well as there are no any issues in recording the data. Some modifications were done to the questionnaires based on these responses. Third, exploratory factor analysis technique was used to reduce data to variables and to explore the underlying theoretical structure of the phenomena. The factor extraction was done with the principle component analysis (PCA) method, whereas factor rotation method was Varimax with Kaiser Normalization. As shown in the following table, the KMO test score is close to 0.5 and the Bartlett's Test of Sphericity is significant $(\mathrm{p}<.05)$. Therefore, this data set is considered to be suitable for the factor analysis.

\section{Table 3: Kaiser-Meyer-Olkin Measure of Sampling Adequacy and Bartlett's Test of Sphericity}

\begin{tabular}{lll}
\hline $\begin{array}{l}\text { Kaiser-Meyer-Olkin } \\
\text { Adequacy }\end{array}$ & Measure of Sampling & .527 \\
$\begin{array}{l}\text { Bartlett's Test of } \\
\text { Sphericity }\end{array}$ & Approx.Chi-square & 2438.970 \\
& Df & 1220 \\
& Sig. & .000 \\
\hline
\end{tabular}

Source: Survey data

As suggested by Hair et al. (2010), all loadings above \pm .40 were considered as factor loadings with practical significance. Consequently, the factor solution is given in Table 4.2. Two factors with Eigenvalues greater than 1 were identified. After extracting factors, the innernal consistency the reliability of each factor was checked with Cronbach's Alpha values which are provided in table 4 . These values were high, which ranged from 0.81-0.89. The factors indicated in this table were named based on underlying conceptual dimensions. After the factor analysis, the calculation of summated scales was done by averaging the original scale responses.

Table 4: Rotated Factor Loading Matrix

\begin{tabular}{|c|c|c|c|}
\hline Questionnaire Items & $\begin{array}{c}\text { Cronbach's } \\
\text { Alpha }\end{array}$ & $\mathrm{CDC}$ & CSSM \\
\hline $\begin{array}{l}\text { Our organization values } \\
\text { managers those who } \\
\text { support to develop } \\
\text { careers of their } \\
\text { employees. }\end{array}$ & .81 & .769 & \\
\hline $\begin{array}{l}\text { We have systems such } \\
\text { as job posting and } \\
\text { position descriptions } \\
\text { that provide information } \\
\text { about career } \\
\text { opportunities in the } \\
\text { organization. }\end{array}$ & .84 & .682 & \\
\hline $\begin{array}{lr}\text { We have } & \text { open } \\
\text { communications so } \\
\text { employees can gain } \\
\text { information about } \\
\text { career opportunities in } \\
\text { the organization. }\end{array}$ & .80 & .722 & \\
\hline
\end{tabular}




\begin{tabular}{|c|c|c|c|}
\hline $\begin{array}{l}\text { Managers } \\
\text { employees' and } \\
\text { responsibilities for } \\
\text { career development are } \\
\text { clearly identified and } \\
\text { stated. }\end{array}$ & .83 & .785 & \\
\hline $\begin{array}{l}\text { Our organization do not } \\
\text { provide access to career } \\
\text { assessment and } \\
\text { planning tools/materials } \\
\text { for employees (R). }\end{array}$ & .81 & .710 & \\
\hline $\begin{array}{lr}\text { Our supervisors } & \text { are } \\
\text { skilled and comfortable } \\
\text { coaching } \\
\text { employees' } \\
\text { development. }\end{array}$ & .85 & .711 & \\
\hline $\begin{array}{l}\text { Our supervisors know } \\
\text { how to help marginal } \\
\text { employees. }\end{array}$ & .88 & .702 & \\
\hline $\begin{array}{l}\text { Our supervisors work } \\
\text { with employees to } \\
\text { enrich their jobs. }\end{array}$ & .81 & .695 & \\
\hline $\begin{array}{l}\text { Our supervisors use } \\
\text { performance appraisals } \\
\text { as a career development } \\
\text { activity. }\end{array}$ & .83 & .684 & \\
\hline $\begin{array}{l}\text { Our supervisors help } \\
\text { employees to explore } \\
\text { career goals. }\end{array}$ & .88 & .720 & \\
\hline $\begin{array}{l}\text { Supervisors know how } \\
\text { to reward and keep top } \\
\text { performers motivated. }\end{array}$ & .80 & .832 & \\
\hline $\begin{array}{l}\text { Our supervisors give } \\
\text { employees frequent, } \\
\text { candid, feedback on } \\
\text { performance. }\end{array}$ & .89 & .683 & \\
\hline $\begin{array}{l}\text { Our employees do not } \\
\text { seek feedback about } \\
\text { their performance from } \\
\text { their supervisors (R). }\end{array}$ & .86 & .754 & \\
\hline $\begin{array}{l}\text { Employees here initiate } \\
\text { new work procedures, } \\
\text { activities and } \\
\text { responsibilities that } \\
\text { helps their careers. }\end{array}$ & .83 & .521 & \\
\hline $\begin{array}{l}\text { Employees have written } \\
\text { career development } \\
\text { plans. }\end{array}$ & .80 & .603 & \\
\hline $\begin{array}{l}\text { Employees like to work, } \\
\text { and develop their } \\
\text { careers as demonstrated } \\
\text { by high morale. }\end{array}$ & .87 & .801 & \\
\hline $\begin{array}{l}\text { Senior } \quad \text { managers } \\
\text { provide } \\
\text { career leadership for } \\
\text { culture change. }\end{array}$ & .86 & & .453 \\
\hline $\begin{array}{l}\text { Senior managers do not } \\
\text { provide role models to } \\
\text { get their people to } \\
\text { change in terms of } \\
\text { career development (R). }\end{array}$ & .89 & & .590 \\
\hline $\begin{array}{lr}\text { Senior } & \text { managers } \\
\text { provide } & \text { continued } \\
\text { encouragement } & \text { to } \\
\text { employees } & \text { for }\end{array}$ & .88 & & .606 \\
\hline
\end{tabular}

\begin{tabular}{|l|l|l|l|}
\hline $\begin{array}{l}\text { participation in career } \\
\text { development. }\end{array}$ & & \\
\hline $\begin{array}{l}\text { Senior Managers } \\
\text { participate in training to } \\
\text { discuss differences on } \\
\text { the assessment as part } \\
\text { of career discussion. }\end{array}$ & & & .505 \\
\hline $\begin{array}{l}\text { We receive } .80 \\
\text { communications from } \\
\text { top management } \\
\text { promoting the career } \\
\text { development program } \\
\text { purposes, need for } \\
\text { changes, and expressing }\end{array}$ & & \\
high level expectations. & & \\
\hline Notes: & & \\
Factor loadings <.4 are suppressed & \\
CDC=Career Development Culture & \\
CSSM=Career Support of Senior Management \\
\hline
\end{tabular}

Source: Survey data.

\section{Testing hypotheses}

Correlations (Table 5) and hierarchical multiple regression analysis were used to test the hypothesized relationships. Cronbach's Alpha values shown in the diagonal of the correlations table are above 0.70 . Therefore, all three scales used in this study are considered as reliable. The main three variables of the study are positively correlated with demographic variables. Therefore, Multiple Hierarchical Regression Analysis allowed control of the effects of demographic variables such as age, gender, and tenure on the hypothesized relationships.

\section{Table 5: Correlation Matrix of Variables}

\begin{tabular}{|c|c|c|c|c|c|c|c|}
\hline & Mean S.D. & & & & & & \\
\hline & & 1 & 2 & 3 & 4 & 5 & 6 \\
\hline 1 Age (Years) & $42.5 \quad 15.7$ & & & & & & \\
\hline 2 Gender & N/A NA & $.431^{* *}$ & & & & & \\
\hline 3 Tenure (Years) & $8 \quad 3.1$ & $.397 * *$ & $.576 * *$ & & & & \\
\hline 4 Career Development Culture & $3.81 \quad .68$ & $.264^{* *}$ & $.314^{* *}$ & $.560^{*}$ & .834 & & \\
\hline $\begin{array}{l}5 \text { Career Support of Senior } \\
\text { Management }\end{array}$ & $3.62 \quad .77$ & $.382 * *$ & $.483^{* *}$ & $.629 * *$ & $.672 * *$ & .899 & \\
\hline 6Career Satisfaction & $3.73 \quad .70$ & $.211^{*}$ & $.533 * *$ & $.751^{* *}$ & $.737 * *$ & $.301^{* *}$ & .812 \\
\hline
\end{tabular}

The results of Multiple Hierarchical Regression Analysis shown in Table 6 indicate that, career satisfaction has significant positive associations with career development culture $(\beta=.502, \mathrm{p}<.05)$ and career support of senior management $(\beta=.477, p<.05)$. As shown in this table, the $\mathrm{R}$ Squared values have been increased significantly from step one to step three when the predictor variables of career development culture and career support of senior management is added respectively to the regression equation. Therefore, these results indicate that, the two hypotheses of the study are accepted indicating that the career development culture and the career support of senior management are determinants of the career satisfaction of employees. 
Table 6: Hierarchical Regression Examining the Impact of Career Development Culture and Career Support of Senior Management on Career Satisfaction

\begin{tabular}{lccc}
\hline & \multicolumn{3}{c}{ Career Satisfaction } \\
\hline Predictors (Beta & Step 1 & Step 2 & Step 3 \\
Coefficients): & & & \\
Age & $.211^{*}$ & $.195^{*}$ & $.175^{*}$ \\
Gender & $.533^{*}$ & $.477^{*}$ & $.399^{*}$ \\
Tenure & $.751^{*}$ & $.672^{*}$ & $.478^{*}$ \\
Career Development & & $.741^{*}$ & $.502^{*}$ \\
Culture & & & \\
Career Support of Senior & & & $.477^{*}$ \\
Management & & & \\
$F$ & $6.618^{*}$ & $6.629^{*}$ & 6.544 \\
Adj. $R$-Squared & $.303^{*}$ & $.371^{*}$ & $.396^{*}$ \\
R-Squared change & .187 & .227 & .306 \\
\hline Note:* ${ }^{*}<.05$ & & &
\end{tabular}

\section{Discussion and Conclusion}

The findings of this study propose that, the organizations should support their employees in terms of creation of a career development culture and providing career support by the senior management, the outcome of which is the increased career satisfaction. Therefore, these outcomes support the notion of sustainability in career development. The study validated two scales, namely 'career development culture scale' and the 'career support of senior management scale', which is also a major contribution of this study.

The current findings provide implications to the extended model of social cognitive career theory (Lent, 2004, 2005; Lent and Brown, 2006), which states that the cognitive, behavioral, personality and environmental factors jointly impact work satisfaction. Thus, this study contributes to the existing literature by exploring how environmental aspects such as career development culture and senior managers support for career development impact career satisfaction.

Moreover, the findings support the prior research outcomes of the positive relationship between organizational support for career development and career satisfaction (Allen, Eby, Poteet, Lentz, \& Lima, 2004; Barnett \& Bradley, 2007; Guan et al., 2015; Guan et al., 2014; Lent \& Brown, 2006; Ng et al., 2005; Orpen, 1994; Pazy, 1988; Price \& Reichert, 2017) and the prediction of the extended model of social cognitive career theory (Lent, 2004, 2005; Lent and Brown, 2006). These are unique findings, since none of the prior empirical studies are found that have investigated career development culture and senior management career support as support factors in this relationship.

The current findings that career development culture and senior management support for career development positively impact on employee career satisfaction suggests us two strategies. First, in order to align organizational career development efforts with business strategy and finally for gaining sustainable competitive advantage, an organization should develop a career development culture and the senior management should support employees' career development in such a way that increase their career satisfaction. The second strategy involves enhancing the employee perception of being supported by developing a career development culture and providing senior management career support acceptable to the employees. Promoting employees to take responsibility and actively involved in career development programs would benefit them to experience higher career satisfaction.

The study is subject to common method and common source bias, since this is a cross sectional study with a survey. The sample of employees do not represent all employee categories which limits the generalizability of findings. There may be more important criteria other than satisfaction with income and progress towards achieving career goals that determine employee career satisfaction, which are not included in the career satisfaction scale developed by Greenhaus et al. (1990).

Future research could be conducted with the representation of broader category of employees and industries, which promotes the generalizability of findings. The replication of the same study on a longitudinal basis is worthwhile to enhance our understanding of the relationships between study variables. Future research could also explore whether career development culture and senior management career support generate other behavioral and attitudinal outcomes such as job satisfaction, commitment and organizational citizenship behavior. As suggested by the extended model of social cognitive career theory (Lent and Brown, 2006), organizational support for career development indirectly affects career satisfaction via context specific proactive behaviors (career management behaviors). Therefore, future studies should investigate whether career development culture and the career support of the senior management influence career satisfaction via career management behaviors.

This study suggested that an organization is likely to attract, motivate and retain employees by supporting their employees' career development in terms of building a conductive career development culture and providing career development support by the senior management. The results of the study suggest that, the career development culture and the senior management support for career development build employee career satisfaction.

\section{References}

Allen, T.D., Eby, L.T., Poteet, M.L., Lentz, E., \& Lima, L. (2004). Career benefits associated with mentoring for proteges: a meta-analysis.Journal of Applied Psychology, 89, 127-135.

Aycan, Z., \& Fikret-Pasa, S. (2003). Career choices, job selection criteria, and leadership preferences in a transitional nation: The case of Turkey. Journal of Career Development, 30(2), 129144.

Aycan, Z., Kanungo, R. N., \& Sinha, J. B. (1999). Organizational culture and human resource management practices: The model of culture fit. Journal of cross-cultural psychology, 30(4), 501-526.

Barnett, B.R., \& Bradley, L. (2007). The impact of organisational support for career development on career satisfaction. Career Development International, 12(7), 617-636. 
Baruch, Y. (2006). Career development in organizations and beyond: Balancing traditional and contemporary viewpoints. Human Resource Management Review, 16, 125-138.

Briggs, E., Jaramillo, F., \& Weeks, W. (2011). Perceived barriers to career advancement and organizational commitment in sales. Journal of Business Research, 65, 937-943.

Claes, R., \& Ruiz-Quintanilla, S. A. (1998). Influences of early career experiences, occupational group, and national culture on proactive career behavior. Journal of Vocational Behavior, 52(3), 357-378.

Erdogan, B., Kraimer, M.L. and Liden, R.C. (2004), "Work value congruence and intrinsic careersuccess: the compensatory roles of leader-member exchange and perceived organizationalsupport",Personnel Psychology, Vol. 57 No. 2, pp. 305-32.

Erdogan, B., Kraimer, M.L., \& Liden, R.C. (2004). Work value congruence and intrinsic career success: the compensatory roles of leader-member exchange and perceived organizational support. Personnel Psychology, 57(2), 305-332.

Evans, P. (1987). Managing career development Journal of Career Development, 7(6), 5-13.

Gottlieb, M.R., \& Conkling, L. (1995). Managing the workplace survivors: organizational downsizing and the commitment gap. Westport, CT: Quorum Books.

Greenhaus, J.H., parasuraman, S., \& Wormley, W. (1990). Effects of race on organizational experiences, job performance evaluations, and career outcomes. Academy of Management Journal, 33(1), 64-86.

Gattiker, U.E., \& Larwood, L. (1988). Predictors for managers' career mobility, success, and satisfaction. Human Relations, 41(6), 569-591.

Guan, Y., Chen, S. X., Levin, N., Bond, M. H., Luo, N., $\mathrm{Xu}$, J., ... \& Zhang, J. (2015). Differences in career decision-making profiles between American and Chinese university students: The relative strength of mediating mechanisms across cultures. Journal of Cross-Cultural Psychology, 46(6), 856-872.

Heslin, P.A. (2005), “Conceptualizing and evaluating career success",Journal of OrganizationalBehavior, Vol. 26 No. 2, pp. 113-36.

Hair, J. F., Black, W. C., Babin, B. J., Anderson, R. E., \& Tatham, R. L. (2010). Multivariate data analysis, 7 th Ed.
Hirschi, A., Jaensch, V. K., \& Herrmann, A. (2016).Protean career orientation, vocational identity, and self-efficacy: an empirical clarification of their relationship.European Journal of Work and Organizational Psychology,26(2), 208-220. pp. 1-13. doi: 10.1080/1359432X.2016.1242481.

Heslin, P.A. (2005). Conceptualizing and evaluating career success. Journal of Organizational Behavior, 26(2), 113-136.

Heslin, P.A. (2003). Self- and other-referent criteria of career success. Journal of Career Assessment, 11(3), 262-286.

Hall, D. T. (2002). Careers in and out of organizations. Thousand Oaks, CA.: Sage.

Huselid. (1995). The impact of human resource management practices on turnover, productivity, and corporate financial performance. Academy of Management Journal, 38, 635-672.

Joo, B.K., \& Park, S. (2010). Career satisfaction, organizational commitment, and turnover intention: The effects of goal orientation, organizational, learning culture and developmental feedback. Leadership \& Organization Development Journal, 31(6), 482500 .

Kotter, J.P., \& Heskett, J.L. (1992). Corporate culture and performance. New York: Free Press.

Kraimer, M.L., Seibert, S.E., Wayne, S.J., Liden, R.C., \& Bravo, J. (2011). Antecedents and outcomes of organizational support for development: the critical role of career opportunities. Journal of Applied Psychology, 96(3), 485-500.

Laabs, J.J. (1996). Expert advice on how to move forward with change. Personnel Journal.

London, M. (1983). Toward a theory of career motivation. Academy of Management Review, 8, 620-630.

Lent, R.W., \& Brown, S.D. (2006). Integrating person and situation perspectives on work satisfaction: a social-cognitive view. Journal of Vocational Behavior, 69, 236-247.

Lent, R.W., Singley, D., Sheu, H. B., Gainor, K.A., Brenner, B.R. , \& Treistman, D. . (2005). Social cognitive predictors of domain and life satisfaction: exploring the theoretical precursors of subjective well-being. Journal of Counseling Psychology, 52(3), 429-442.

Mendonca, M., \& Kanungo, R. N. (1994). Managing human resources: The issue of cultural fit. Journal of Management Inquiry, 3(2), 189-205. 
Mayo, A. (1991). Managing careers. London: IPM. Moorman, C., \& Miner, A.S. . (1998). Organizational improvisation and organizational memory. Academy of Management Review, 23(4), 698-723.

Mendonca, M., \& Kanungo, R. N. (1994). Managing human resources: The issue of cultural fit. Journal of Management Inquiry, 3(2), 189-205.

Ng, T.W.H., Eby, L.T., Sorensen, K.L. , \& Feldman, D.C. (2005). Predictors of objective and subjective career success: a meta-analysis. Personnel Psychology, 58, 367-408.

Orpen, C. (1994). The effects of organizational and individual career management on career success. International Journal of Manpower, 15(1), 27-37.

Pazy, A. (1988). Joint responsibility: The relationships between organizational and individualcareer management and the effectiveness of careers. Group and Organization Studies, 13(3), 311331.

Portis, B. (1978). Career development requires senior executive involvement/management initiatives. Business Quarterly, 43(3), 9-11.

Price, S., \& Reichert, C. (2017). The importance of continuing professional development to career satisfaction and patient care: meeting the needs of novice to mid-to late-career nurses throughout their career span. Administrative Sciences, 7(2), 17.

Simonsen, P. (1997). Promoting a development culture in your organization: using career development as a change agent (1 ed. Vol. 1). Palo Alto, California: Davies-Black Publishing.

Schein, E. H. (1985). Defining organizational culture. Classics of organization theory, 3(1), 490-502.

Schuler, R.S., \& Jackson, S.E. (1987). Linking competitive strategies with human resource management practices. Academy of Management Executive, 1, 207-219.

Sturges, J., Guest, D., Conway, N., \& Davey, K.M. (2002). A longitudinal study of the relationship between career management and organizational commitment among graduates in the first ten years at work. Journal of Organizational Behavior, 23, 731-748.

Seibert, S.E., \& Kraimer, M.L. (2001). The five-factor model of personality and career success. Journal of Vocational Behavior, 58, 1-21.
Yates, J. (2020). Career Development: An Integrated Analysis. In: Robertson, P., McCash, P. and Hooley, T. (Eds.), The Oxford Handbook of Career Development. . Oxford, UK: Oxford University Press. ISBN 9780367222994.

Yuen, E.C., \& Kee, H.T. (1993). Headquarters, host culture and organizational influences on HRM policies and practices. Management International Review, 33(4), 361-383.

Van der Heijden, B., De Vos, A., Akkermans, J., Spurk, D., Semeijn, J., Van der Velde, M., \& Fugate, M. (2020). Sustainable careers across the lifespan: Moving the field forward. Journal of Vocational Behavior.

Van der Heijden, B. I., \& De Vos, A. (2015). Sustainable careers: Introductory chapter. In Handbook of research on sustainable careers. Edward Elgar Publishing.

Van der Heijden, B. I. (2005). No one has ever promised you a rose garden. Uitgeverij Van Gorcum.

Veld, M., Semeijn, J., \& van Vuuren, T. (2015). Enhancing perceived employability. Personnel Review.

Walters, M. (1992). Career Management: current thinking and practice. Topics, 54, 10-14. https://lmd.lk/bestworkplacesinsrilanka/ 